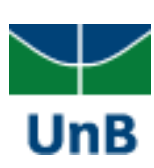

Universidade de Brasília Instituto de Ciências Humanas

Departamento de Geografia

\title{
OCUPAÇÃO IRREGULAR DE TERRAS E CRIAÇÃO DE CENTROS DE DESENVOLVIMENTO ECONÔMICO EM CEILÂNDIA - DF
}

Maria das Neves Almeida Pessoa

Orientador: Professor Doutor Neio Campos

Dezembro de 2009 
Universidade de Brasília

Instituto de Ciências Humanas

Departamento de Geografia

\section{OCUPAÇÃO IRREGULAR DE TERRAS E CRIAÇÃO DE CENTROS DE DESENVOLVIMENTO ECONÔMICO EM CEILÂNDIA - DF}

Maria das Neves Almeida Pessoa

Monografia de Prática e Pesquisa de Campo II submetida ao Departamento de Geografia do Instituto de Ciências Humanas da Universidade de Brasília como parte dos requisitos para a obtenção do grau de Bacharelado em Geografia.

\section{Professor Doutor Neio Campos}

Departamento de Geografia - Universidade de Brasília

Professor Gilberto Alves de Oliveira Junior

Departamento de Geografia - Universidade de Brasília

\section{Professora Nelba Azevedo Penna}

Departamento de Geografia - Universidade de Brasília 


\section{FICHA CATALÓGRAFICA}

PESSOA, Maria das Neves Almeida. “Ocupação Irregular de Terras e Criação de Centros de Desenvolvimento Econômico em Ceilândia - DF”. (GEA - IH - UnB, Bacharel em Geografia, 2009). Monografia de Prática e Pesquisa de Campo II. Universidade de Brasília. Instituto de Ciências Humanas. Departamento de Geografia.

I - Expansão Urbana

II - Desenvolvimento Econômico

III - Planejamento Territorial.

\section{REFERÊNCIA BIBLIOGRÁFICA}

PESSOA, Maria das Neves Almeida. "Ocupação Irregular de Terras e Criação de Centros de Desenvolvimento Econômico em Ceilândia - DF”. Monografia de Prática e Pesquisa de Campo II. Universidade de Brasília. Instituto de Ciências Humanas. Departamento de Geografia, 2009.

\section{CESSÃO DE DIREITOS}

Autoria: Maria das Neves Almeida Pessoa

Título: "Ocupação Irregular de Terras e Criação de Pólos de Desenvolvimento Econômico em Ceilândia - DF".

Grau: Bacharel, 2009.

É concedida à Universidade de Brasília permissão para reproduzir cópias desta monografia e, ainda, emprestar e/ou vender cópias, desde que sejam destinadas para propósitos acadêmicos ou científicos. A autora reserva outros direitos de publicação e nenhuma parte desta monografia pode ser reproduzida sem a devida autorização, por escrito, por ela mesma. 
À minha família, que esteve presente em todos os momentos de minha vida, apoiando e incentivando. 


\section{AGRADECIMENTOS}

Agradeço a Deus que tem me dado força e ânimo para prosseguir até aqui; ao professor Neio Campos que me ajudou com bons conselhos e sábias observações durante vários semestres; à colega Claudia Varizo que me forneceu dados e documentos valiosos para a elaboração do trabalho; à minha irmã Neiri que tem sido sempre um exemplo a seguir e uma das principais incentivadoras ao meu estudo e ao meu namorado Cleisson Pessoa que demonstrou muito afeto e paciência durante esse longo processo de estudo e trabalho. 


\section{RESUMO}

O presente trabalho visa uma análise da dinâmica da expansão urbana na área de Ceilândia e a implantação de áreas de desenvolvimento econômico. Por meio de pesquisa bibliográfica buscou-se a identificação das áreas de expansão urbana em Ceilândia, em especial das áreas de ocupação irregular com o fim de estabelecer uma relação entre a concentração demográfica e o desenvolvimento econômico, considerando para tal análise que o fator da aglomeração humana sobre o território pode vir a ser um dos fatores de indução do crescimento em termos de economia.

No mesmo sentido, fez-se necessário a caracterização das áreas de desenvolvimento econômico em Ceilândia e buscou-se estabelecer as diferenças entre o modelo de desenvolvimento implantado, por meio do programa Pró-DF II, pelo Governo do Distrito Federal e o modelo de crescimento proposto por Perroux. Bem como a caracterização das áreas de ocupação irregular que impõe ao Governo do Distrito Federal a dificuldade de articular políticas de crescimento econômico e ao mesmo tempo de contenção da malha urbana.

\section{PALAVRAS CHAVES:}

Expansão Urbana; Desenvolvimento Econômico e Planejamento Territorial 
SUMÁRIO

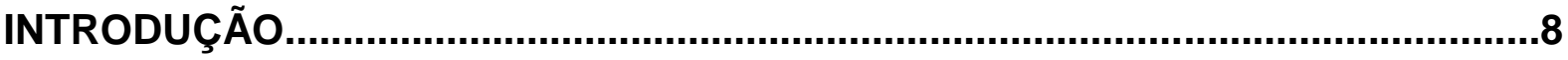

1 ASPECTOS DA DINÂMICA DA CONFIGURAÇÃO URBANA BRASILEIRA E O PROBLEMA DA REGULARIZAÇÃO FUNDIÁRIA.............................................13

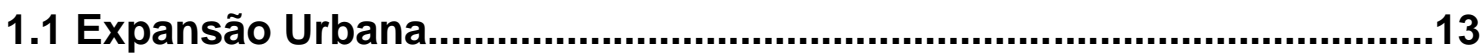

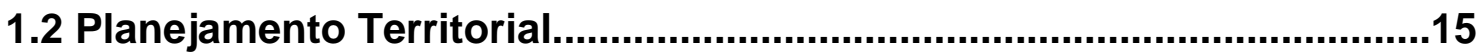

1.3 Regularização Fundiária...........................................................................17

20 CONTEXTO DA OCUPAÇÃO IRREGULAR DE TERRAS NA CEILÂNDIA......25

2.1 O Espaço Urbano de Ceilândia no DF.....................................................25

2.2 Ocupação Irregular de Terras em Ceilândia.............................................30

3 O PROGRAMA DE APOIO AO DESENVOLVIMENTO PRODUTIVO - PRÓ-DF NA CEILÂNDIA: DIFERENÇAS ENTRE O MODELO IMPLANTADO E A IDEIA DE PÓLOS DE CRESCIMENTO DE FRANÇOIS PERROUX.......................................35

3.1 Idéia de pólo de crescimento de François Perroux................................35

3.2 Programa de Apoio ao Desenvolvimento Produtivo - Pró-DF................39

3.2.1 ADE's em Ceilândia.................................................................................42

3.2.2 ADE Centro-Norte em Ceilândia .......................................................43

3.2.3 ADE Setor de Indústria em Ceilândia..................................................46

3.2.4 ADE Setor de Materiais de Construção em Ceilândia...........................48

3.3 ATÉ QUE PONTO AS ÁREAS DE DESENVOVIMENTO ECONÔMICO EM CEILÂNDIA FUNCIONAM COMO IMPULSIONADORAS DA GERAÇÃO DO DESENVOVIMENTO PARA A REGIÃO....................................................50

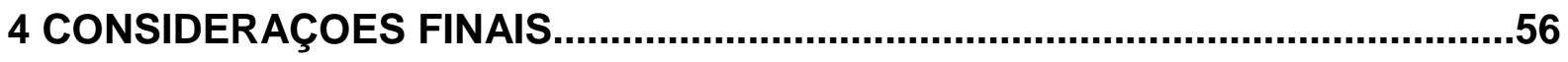

REFERÊNCIAS BIBLIOGRÁFICAS............................................................58 


\section{INTRODUÇÃO}

A ocupação irregular de terras dá origem aos principais problemas urbanos. Problemas como desarticulação do sistema viário, formação de bairros sujeitos à erosão e alagamentos, assoreamento de rios, ausência de espaço público para implantação de equipamentos de saúde, educação, lazer e segurança, comprometimento dos mananciais de abastecimento de água e do lençol freático, ligações clandestinas de energia, resultando em risco de acidentes e incêndios e expansão da malha urbana.

A ocupação irregular pode ocorrer de três formas: a primeira é quando o proprietário parcela seu terreno, sem cumprir os procedimentos estabelecidos em lei; a segunda é denominada grilagem e ocorre quando uma pessoa vende terrenos que não lhe pertencem e a terceira é a ocupação pelos próprios moradores, seja por ocupações coletivas organizadas por movimentos, seja por ocupações individuais ao longo do tempo.

Quando se iniciou o processo de transferência da capital para o quadrilátero do Distrito Federal, vários terrenos foram desapropriados para que pudessem dar espaço aos atuais núcleos urbanos. De acordo com estudos realizados pela CODEPLAN - Companhia de Planejamento do Distrito Federal, em 1997, cerca de $51,36 \%$ das terras do DF foram integralmente desapropriadas, $33,28 \%$ ainda estavam em mãos de particulares, $8,53 \%$ foram desapropriadas parcialmente e 6,83\% estavam em processo de desapropriação. A política fundiária adotada ao longo dos anos favoreceu a especulação fundiária e fez com que o patrimônio fundiário do DF fosse gerenciado de forma desvinculada da política habitacional e fora de uma perspectiva social. 
O Distrito Federal consiste em um território autônomo na federação e a Constituição brasileira de 1988 veda a sua divisão em municípios. Entretanto, foram criadas a fim de abrigar a sua população as cidades-satélites. As primeiras cidadessatélites surgiram em 1956 e são Candangolândia e Núcleo Bandeirante, em 1958 foi criado Taguatinga, em 1959 o Cruzeiro, em 1960 Sobradinho e Gama, em 1968 o Guará, em 1971 a Ceilândia, em 1989 Samambaia e Paranoá. E em 1993, outras quatro: Santa Maria, São Sebastião, Recanto das Emas e Riacho Fundo. Em 1994, surgiu o Lago Sul, o Lago Norte e a Candangolândia. Duas das cidades-satélites antecedem a criação do Distrito Federal, Planaltina e Brazlândia.

Após o crescimento demográfico verificado em 1960 e 1970, o crescimento populacional decaiu. Mesmo assim, na década de 1990, a população salta de 1,6 milhão para 2 milhões de habitantes, o que representa um crescimento de $2,8 \%$, superado apenas pelos estados da Região Norte.

No âmbito da urbanização brasileira, Brasília apresentou uma ocupação diferenciada, visto que, nasceu com a função de capital administrativa. Tal função presumia planejamento da cidade e de certa forma um controle social, que evitasse problemas tão comuns nas demais regiões metropolitanas. Contudo o rápido processo de construção da nova capital exigiu uma grande mobilização da força de trabalho, atraindo um grande contingente de migrantes para o Distrito Federal.

Segundo Quinto Jr. e Iwakami (1991), a ocupação das cidades satélites se deu pela necessidade de dar respostas à forma como ocorreu a construção de Brasília. A construção da nova capital em menos de quatro anos requisitou o uso de mão de obra de forma extensiva. Trabalhadores de várias cidades brasileiras chegaram ao quadrilátero do Distrito Federal e foram dando origem a inúmeros assentamentos em torno do Plano Piloto. Sendo assim, a criação das cidades- 
satélites está intimamente ligada à construção de Brasília, visto que a remoção dos assentamentos foi uma forma de evitar aglomerações no centro da cidade e não deixar de lado o projeto previsto para a capital.

O presente estudo tem como objetivo geral analisar a relação entre ocupação irregular de terras na Ceilândia e a dinamização das atividades econômicas na região, tomando como referência as Áreas de Desenvolvimento Econômico (ADE) previstas no Plano Diretor de Ordenamento Territorial (PDOT). Para alcançar este objetivo destacamos como objetivos específicos:

- Identificar as áreas de ocupação irregular e em fase de regularização de Ceilândia.

- Caracterizar as áreas de desenvolvimento econômico de Ceilândia.

- Caracterizar o Programa de Apoio ao Desenvolvimento Produtivo - PróDF identificando seus objetivos, benefícios oferecidos e metas alcançadas.

- Caracterizar a oferta de empregos nas áreas beneficiadas pelo Pró-DF em Ceilândia.

- Analisar do Programa Pró - DF implantando em Ceilândia frente à concepção de Pólo de Crescimento.

As cidades satélites do Distrito Federal sempre apresentaram um elevado índice de dependência econômica em relação ao Plano Piloto. Neste sentido, este trabalho enseja o debate para que se busquem políticas no sentido de desenvolver economicamente as cidades satélites, em especial a cidade de Ceilândia, por meio das ADE's já instituídas e verificar em que medida é possível elevar o nível de atividades econômicas em função do aumento da demanda populacional, verificado por meio da expansão urbana. 
A ocupação irregular de terras apresenta-se como um entrave ao planejamento urbano. Entretanto, ela pode oferecer um avanço ao crescimento econômico nas localidades onde são implantadas desde que hajam políticas públicas adequadas, visto que a concentração demográfica pode ser um fator relevante para instalação de atividades econômicas, pois se aumenta no local a demanda por serviços e bens de consumo, além de ofertar mais de mão-de-obra.

Os procedimentos metodológicos para o alcance do objetivo geral deste estudo consistem nas seguintes etapas:

$1^{\circ}$ Etapa: Identificação das áreas de ocupação irregular e em fase de regularização de Ceilândia por meio de pesquisa bibliográfica em relatórios preliminares cedidos pela Secretária de Desenvolvimento Urbano e Meio Ambiente - SEDUMA:

$2^{\circ}$ Etapa: Caracterização das áreas de desenvolvimento econômico de Ceilândia por meio de pesquisa em fontes secundárias, principalmente documentos da Secretaria de Estado e Planejamento do Governo do Distrito Federal (GDF).

$3^{\circ}$ Etapa: Caracterização do Programa de Apoio ao Desenvolvimento Produtivo Pró - DF a partir de estudo técnico de responsabilidade da Secretária de Estado de Desenvolvimento Econômico e Turismo, apontando seus objetivos, benefícios e metas alcançadas.

$4^{\circ}$ Etapa: Caracterização da oferta de empregos nas áreas beneficiadas pelo Pró DF, a partir dos dados da empresa Sete Serviços Técnicos Especializados Ltda. 
5 Etapa: Análise do Programa Pró - DF implantando em Ceilândia frente à concepção de Pólo de Crescimento por meio de fontes secundárias.

Esta monografia está estruturada em três capítulos. O primeiro capítulo trata sobre aspectos da dinâmica da configuração urbana brasileira e o problema da regularização fundiária. O segundo capítulo discorre sobre o contexto da ocupação irregular de terras em Ceilândia. E o terceiro e último capítulo apresenta a análise do Programa de Apoio ao Desenvolvimento Produtivo - Pró-DF em Ceilândia e a concepção de Pólo de Crescimento. 


\section{ASPECTOS DA DINÂMICA DA CONFIGURAÇÃO URBANA BRASILEIRA E O PROBLEMA DA REGULARIZAÇÃO FUNDIÁRIA}

\subsection{Expansão Urbana}

A configuração atual do Brasil é resultado de um longo processo de mudanças e transformações. Segundo Santos (2001), a organização do país se deu em três períodos: o dos meios naturais, o técnico e o técnico - científicoinformacional. Nesse processo o principal agente é o homem. E novas áreas, seja por interesse político ou econômico, passam a ser exploradas e povoadas.

Não há dúvida que as cidades brasileiras cresceram de forma desordenada e apresentam inúmeros problemas pela falta de planejamento. Isso aconteceu pelo rápido processo de urbanização no Brasil, enquanto os países desenvolvidos levaram de 100 a 200 anos para se tornarem urbanos, o Brasil se urbanizou em apenas 50 anos, num processo que ocorreu concomitantemente ao de industrialização e não decorrente dele, como nos países europeus.

Até a década de 70 houve no Brasil uma tendência à concentração populacional e aos investimentos econômicos em cidades de grande porte, mas essa concentração tende a gerar situações adversas como as deseconomias de aglomeração, que são o encarecimento da terra, a falta de mão-de-obra qualificada, elevação dos valores de impostos, a falta de investimento em infra-estrutura, em comunicação e transporte, iniciando-se assim um redirecionamento dos fluxos para 
outras cidades formando novos centros com potencial para receber novos fluxos de investimentos e populacionais.

As cidades podem crescer por crescimento vegetativo ou por migrações, mas a tendência geral é que cresçam por migrações. As regiões metropolitanas tendem também a ter um crescimento populacional maior em virtude do maior desenvolvimento econômico.

Há várias teorias sobre crescimento urbano e sobre os aspectos que fazem uma cidade crescer. É comum em todas elas ressaltar-se que a cidade é o lugar do mercado, onde estão os bens, serviços, mão-de-obra, sindicatos, etc., e é onde ocorre a troca de mercadorias. Nesse sentido a cidade se apresenta como lugar central.

Outro fator de crescimento se encontra no potencial de inovação e adaptação que necessitam da concentração para se efetivarem e se difundirem. A informação gerada pela proximidade das pessoas e atividades também é um importante fator para o crescimento das cidades, além das atividades públicas que se seguem às concentrações populacionais e econômicas ou as que ocorrem concomitantemente.

Como ressalta Ermínia Maricato em seu artigo Dimensões da tragédia urbana, é comum que o crescimento urbano se dê de forma ilegal e muitas vezes, como é o caso de Brasília, com o incentivo e apoio do governo local. Os loteamentos e construções irregulares surgem como alternativa para a falta de políticas públicas no âmbito da habitação e realçam aspectos da segregação sócio espacial no país. É difícil mensurar em que nível se encontra tais ocupações, mas é evidente a necessidade de se planejar e elaborar estratégias para uso e ocupação de áreas urbanas. 


\subsection{Planejamento Territorial}

No Brasil, desde a década de 40, o planejamento tem servido de alavanca para o crescimento do país. Um dos primeiros planos econômicos desenvolvidos foi

o SALTE, esse plano tinha como objetivo o desenvolvimento de setores da saúde, alimentação, transporte e energia, daí surgiram as siglas que deram origem ao seu nome, ele foi elaborado por vários ministérios durante e o governo de Eurico Gaspar Dutra. A cada nova administração se traçavam novos planejamentos e metas, embora nem todos bem sucedidos, e desde então, cada governo foi marcado por um conjunto de medidas que levariam ao crescimento do país.

Planejamento, em sentido estrito, significa a formulação da intervenção do Estado na produção e reprodução social. O planejamento tem como objetivo assegurar condições de reprodução da sociedade. O planejamento se desenvolve em estágio de desenvolvimento intenso, onde há necessidade de ordenação e estruturação das grandes aglomerações urbanas, onde suas prioridades são a infraestrutura e o uso do solo.

Souza (2003) destaca quatro elementos fundamentais da atividade de planejamento: o pensamento orientado para o futuro; a escolha entre alternativas; a consideração dos limites, restrições e potencialidade - consideração de prejuízos e benefícios; e a possibilidade de diferentes cursos de ação, os quais dependem de condições e circunstâncias variáveis. Há que se destacar ainda um quinto elemento: 
a preocupação com a resolução de conflitos de interesses, sugerindo a busca pelo ideal harmônico.

O planejamento urbano se faz necessário, sobretudo, em cidades onde o crescimento urbano ocorreu de forma desordenada e gerou grande segregação social e territorial. Embora não se saiba ao certo o número de loteamentos clandestinos, onde as pessoas vivem sem a menor infra-estrutura, é latente a necessidade de identificar esses lugares e se elaborar políticas que amenizem essa situação e regularizem a apropriação e uso do solo.

O planejamento territorial urbano promovido pelo Ministério das Cidades para as cidades brasileiras tem como objetivos gerais: apoiar os municípios na implementação do Estatuto da Cidade; ampliar o acesso, por parte da população de menor renda, à terra urbanizada; promover a integração, em todos os níveis de governo, de programas de regularização (urbanização e legalização) com políticas includentes de planejamento urbano; promover a integração e coordenação, em todos os níveis de governo, das ações nas áreas urbanas centrais, propiciando sua ocupação em contraposição à expansão periférica das cidades e promover o reconhecimento de maneira integrada dos direitos sociais e constitucionais de moradia e preservação ambiental, qualidade de vida humana e preservação de recursos naturais. E como objetivos específicos: promover o reconhecimento dos novos direitos e sua plena utilização, enfatizando que são formas de direito real de propriedade; priorizar soluções coletivas a problemas que são coletivos; buscar a remoção dos obstáculos da legislação federal fundiária, cartorária, urbanística e ambiental; incentivar parcerias com a sociedade civil, promovendo ampla participação popular em todas as etapas das intervenções de regularização fundiária 
e criar uma rede de instituições não-governamentais e entidades profissionais que atuem no apoio técnico à gestão urbana.

\subsection{Regularização Fundiária}

Desde o inicio da urbanização brasileira priorizou-se o saneamento e embelezamento das cidades, que acabaram por expulsar os pobres para as periferias. Ao mesmo tempo em que se investia em obras paisagísticas para valorização do mercado imobiliário nos centros, se investia também em infraestrutura para instalação de indústrias entre os centros e a periferia. A fim de obter desenvolvimento, as políticas públicas contribuíam para aumentar a especulação imobiliária, à medida que ia ocupando os espaços vazios e de certa forma penalizando os mais pobres, que financiavam esses projetos.

As primeiras leis para ordenar a ocupação das cidades acabaram gerando um movimento segregacionista empurrando a população de baixa renda para a periferia das cidades e até estimulando as ocupações irregulares. Os padrões de ocupação brasileira determinavam cidades ideais, contribuindo assim para a valorização do espaço urbano e para a conseqüente segregação urbana.

Em pesquisa do IBGE (Instituto Brasileiro de Geografia Estatística) de 1995, comprovou-se que existe um déficit habitacional de 5,4 milhões de unidades de domicílios, e em censo realizado em 2000 verificou-se 4,5 milhões de domicílios vagos, evidenciando a necessidade de uma política urbana que tornem as 
propriedades socialmente justas, como define a Lei de Responsabilidade Territorial Urbana.

Sem possibilidade de ocupar áreas legais, boa parte da população se vê obrigada a residir em lugares afastados, em favelas, cortiços, loteamentos clandestinos, casas de fundos, em baixo de viadutos, beira de rios e até mesmo em cima de árvores. A falta de políticas públicas urbanas para população de baixa renda é um problema social enorme, visto que a falta de tais políticas gera, entre outras coisas, a marginalidade e a ocupação de áreas ilegais.

Em âmbito federal temos duas leis que se complementam em relação ao ordenamento territorial, a Lei $n^{\circ} 6.766$ de 1979 e a Lei $n^{\circ} 10.257$ de 2001 . Ambas poderão ter seus dispositivos regulamentados em complementaridade com legislação local específica e são parâmetros para elaboração tanto do Plano Diretor de Ordenamento Territorial quanto dos Planos Diretores Locais.

A Lei no 6.766/79 (Lei de parcelamento do solo urbano) dispõe sobre o parcelamento de solo urbano e estabelece parâmetros e diretrizes para tal, priorizando o parcelamento do solo e a regularização fundiária por meios de políticas que zelem pela função social da cidade, com a oferta de moradia à população, desde que respeitados a ordem pública e urbanística, e também o meio ambiente ecologicamente equilibrado.

A Lei $n^{\circ} 6.766 / 79$ define loteamento como a subdivisão da gleba em lotes destinados à edificação, com abertura de novas vias de circulação, de logradouros públicos ou prolongamento, modificação ou ampliação das vias existentes. Estabelece também uma proporcionalidade entre áreas destinadas à moradia e equipamentos públicos e de infra-estrutura. 
Desde sua criação a Lei de parcelamento urbano tem sofrido algumas alterações com intuito de se adaptar à realidade de ocupação das áreas urbanas. A Lei Federal n 9.785 de 29 de janeiro de 1999, além de alterar a Lei n 6.766/79, traz uma nova redação e uma preocupação maior com as zonas habitacionais de interesse social (ZHIS), permite parcelamento de solo para fins urbanos somente em zonas de expansão urbana, em áreas de expansão urbana ou de urbanização específica definidas pelo PDOT ou aprovadas por lei municipal.

No ano de 2000 foi aprovado pela Comissão Especial da Câmara dos Deputados o projeto de Lei $n^{\circ} 3.057$ com o intuito de regulamentar e controlar a ocupação do solo urbano, principalmente a de condomínios fechados. A Lei de Responsabilidade Territorial, assim denominada, é uma ampla revisão da Lei $\mathrm{n}^{\circ}$ 6.766 de 1979 e visa à integração das políticas de ocupação do solo e de regularização fundiária em nível federal e dá autonomia aos municípios para estabelecerem um ordenamento específico respaldados em seus Planos Diretores Locais.

De acordo com a Secretaria Nacional de Programas Urbanos - SNPU o Projeto de Lei aprovado avança ao estabelecer instrumentos que permitem aos Municípios exercerem plenamente sua atribuição constitucional de implementar a política de desenvolvimento urbano com sustentabilidade ambiental e justiça social.

A Lei ํo 10.257 de 10 de junho de 2001, denominada Estatuto das Cidades regulamenta a política urbana presente na Constituição Federal de 1988 em seus artigos 182 e 183. Ela regula o uso da propriedade urbana em defesa do bem coletivo, da segurança e do bem-estar dos cidadãos, bem como o equilíbrio ambiental, conforme disposto no artigo $1^{\circ}$ desta lei. 
Rodrigues (2005: 92) aponta que o Estatuto inovou ao reconhecer a cidade real, ou seja, ao "tirar das sombras" os problemas e conflitos que permeiam a população urbana. Reconheceu a necessidade de legitimar, legalizar as áreas ocupadas por moradias; estabeleceu novos critérios para parcelamento do solo; incluiu a obrigatoriedade de participação da sociedade civil na elaboração do Plano Diretor Municipal.

O artigo $2^{\circ}$ do Estatuto da Cidade destaca o objetivo da política urbana que é ordenar o pleno desenvolvimento das funções sociais da cidade e da propriedade. De acordo com Meirelles (1993: 377), são consideradas funções sociais da cidade: a habitação, o trabalho, a circulação e a recreação.

O Estatuto da Cidade em seu artigo 39 dispõe que "a propriedade urbana cumpre sua função social quando atende às exigências fundamentais de ordenação da cidade expressas no plano diretor, assegurando o atendimento das necessidades dos cidadãos quanto à qualidade de vida, à justiça social e ao desenvolvimento das atividades econômicas, respeitadas as diretrizes previstas no artigo $2^{\circ}$ ".

O Estatuto indica instrumentos da política urbana dentre os quais o planejamento municipal das regiões metropolitanas, aglomerações urbanas e microrregiões. Dentre os principais instrumentos da política urbana, destacam-se além do planejamento em diversas escalas, institutos tributários e financeiros como o IPTU e incentivos e benefícios fiscais, institutos jurídicos e políticos como a desapropriação, o tombamento de imóveis, a instituição de unidades de conservação, o parcelamento, a edificação ou a utilização compulsória, concessão do direito real de uso, concessão de uso especial para fins de moradia, usucapião especial de imóvel urbano e a outorga onerosa do direito de construir e de alteração. 
O pressuposto do Estatuto da Cidade, como ressalta Rodrigues (2005: 104), que a cidade é um bem coletivo e que as propriedades devem cumprir sua função social, refere-se à apropriação, à propriedade e ao uso do solo, desta forma, faz-se necessário verificar a definição de não edificado, subutilização ou não utilização de imóveis para analisar quando cumprem sua função social. Esta autora, conforme já dito anteriormente, aponta que o Estatuto impõe limite à especulação imobiliária, contudo é preciso verificar as formas pelas quais ocorre a retenção de imóveis (edificados ou não), para "valorização futura". Neste sentido, Rodrigues (2005: 104) alerta que a ausência de critérios básicos para definir quando uma propriedade urbana está aguardando valorização futura, inclusive para averiguar se está cumprindo sua função social e aplicar os instrumentos do Estatuto. A solução apontada por Rodrigues (2005: 106) é a elaboração de parâmetros para analisar a improdutividade ou subutilização.

Outro alerta de Rodrigues (2005: 96) refere-se à implantação de empreendimentos que não observam o urbano, o território, pois ao planejar uma atividade, visa-se obter interesses específicos: "os estudos e planos de atuação são fechados em circuitos isolados, fragmentados em relação ao território e não possibilitam participação social” (2005: 96). Mais para frente, ainda complementa este pensamento ao afirmar que o planejamento setorializado não leva em conta a dinâmica espacial e socioambiental (2005: 98), não considera a reprodução da vida e o espaço. Nas palavras de Rodrigues (2005: 101): "mostra a permanência do paradigma de um planejamento que atenta apenas aos interesses específicos".

O Distrito Federal possui uma peculiaridade no âmbito do reordenamento territorial da cidade, a maior parte das terras desocupadas é de propriedade do governo. Isso porque na data da construção de Brasília quase todas as propriedades 
privadas foram desapropriadas. Cabe ao governo, então, programar políticas que visem uma socialmente justa distribuição da terra urbana.

A cidade foi marcada pelo dualismo entre o Plano Piloto e as não planejadas cidades-satélites. À medida que novas áreas eram invadidas, novas cidades satélites eram construídas. A primeira medida adotada a fim de promover uma melhor distribuição da terra urbana foi a criação da Sociedade de Habitações de Interesse Social Ltda (SHIS) em 1962. A distribuição dos lotes era feita por meio de um cadastro e mediante alguns critérios, como renda e tempo de residência em Brasília.

A política de desenvolvimento urbano do Distrito Federal, prevista na Lei Orgânica do Distrito Federal criada em 1993, visa garantir a função social da propriedade, e a melhoria da qualidade de vida da população mediante a adequada distribuição das atividades socioeconômicas e dos equipamentos urbanos e comunitários de forma compatível com a preservação ambiental e cultural. Visa também à implantação de assentamentos urbanos para atender a demanda populacional do Distrito Federal, mas veda a criação de assentamentos urbanos sem a presença de infra-estrutura e sem saneamento básico.

No Distrito Federal, o conceito de loteamento se confunde ao de condomínio, sendo o último muito mais utilizado para designar os parcelamentos aqui existentes do que o primeiro. Contudo, o melhor termo para designar tais ocupações é mesmo o de loteamento, pois cada morador tem apenas a posse ou cessão de direito da terra, e as ocupações em geral tem inicio na grilagem de terras, constituindo-se em loteamento irregular.

Os "condomínios" irregulares representam para o governo do Distrito Federal um grave problema, pois além de abrigarem a população de classe média, 
também tem sido alvo da população de renda mais baixa, que assim como os primeiros não encontram outras opções de moradia. Em 1992, ano da promulgação do primeiro Plano Diretor de Ordenamento Territorial do Distrito Federal, já havia cerca de 200 loteamentos irregulares. Em 1999, existiam 529 processos sobre parcelamento de solo urbano no Distrito Federal. Processos gerados pela falta de oferta de habitação a todas as esferas da sociedade, dando origem a loteamentos irregulares tanto de baixa renda quanto de classe alta, que buscam moradias mais próximas do centro onde estão seus locais de trabalho, lazer e escolas de seus filhos.

Quanto aos mais pobres, ocupam quaisquer áreas que não tenham sido ocupadas anteriormente, usando para isso restos de materiais de construção e sacos plásticos. Essa população conta com o apoio do governo, que em seguida regulariza a área e proporciona além da instalação de saneamento básico e infraestrutura, também a construção de habitações mais dignas. A postura do governo acaba gerando um ciclo de novas ocupações.

O Decreto $\mathrm{n}^{\circ}$ 21.950, de 12 de fevereiro de 2001, considera como irregular todas as ocupações não autorizadas de áreas públicas urbanas a título de moradia, bem como aquelas que não possuam documento que lhe autorize a permanência no imóvel, seja por o cedente se encontrar em situação irregular, ou por falta de documentação.

Para evitar o alastramento das invasões no Distrito Federal, o Poder Executivo criou normas para remoção das invasões. São retiradas as invasões localizadas em áreas de situação de risco, periculosidade ou insalubridade, sendo que as invasões mais recentes serão retiradas antes das mais antigas, e primeiro as 
em situação que desrespeitam a Lei de Seguridade Social e em seguida as que desrespeitem legislação urbana, citada no parágrafo anterior.

Como uma forma de atender a demanda por moradia, o governo busca de forma imediatista e paliativa, a regularização dos condomínios e invasões. Deve-se observar que a regularização sem planejamento pode gerar mais danos que benefícios a cidade, que por si só já tem muitos problemas. 


\section{O CONTEXTO DA OCUPAÇÃO IRREGULAR DE TERRAS NA CEILÂNDIA}

\subsection{Espaço Urbano de Ceilândia no DF}

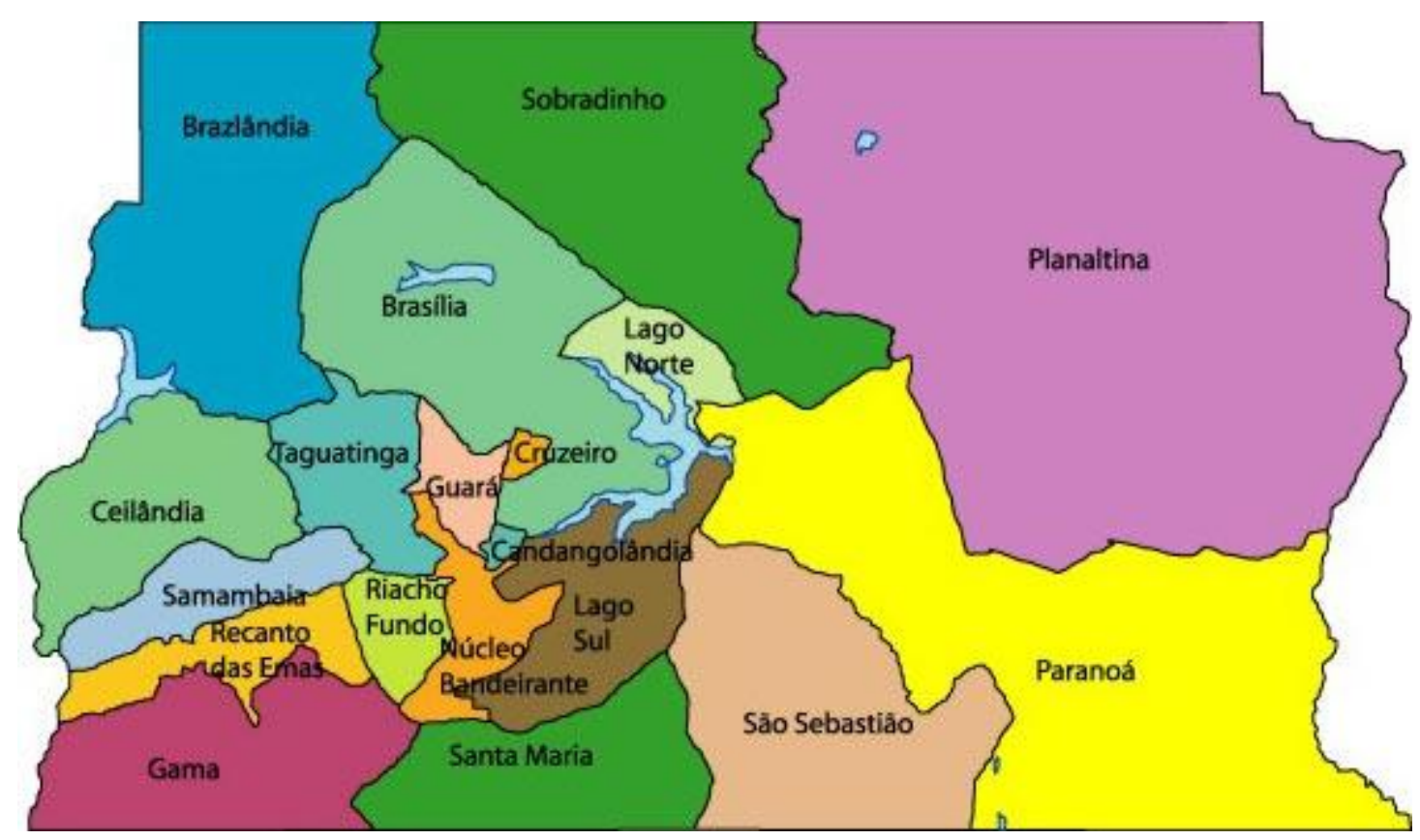

llustração 1: Mapa das regiões administrativas do DF Fonte: $\underline{w w w . s e t u r . d f . g o v . b r}$

Ceilândia é fruto do modelo de planejamento que se perpetuou em Brasília ao longo dos anos. Antes de descrever como se deu a criação da cidade-satélite, buscaremos uma análise do que foi a criação de Brasília e como dela resultou esse modelo urbano que conhecemos hoje.

Segundo Steinberger (1999), Brasília não deve ser trata apenas como Plano Piloto ou quadrilátero do Distrito Federal. Brasília deve ser considerada como um aglomerado urbano, que possui um núcleo, o Distrito Federal, cuja sede é o Plano Piloto, diversos núcleos secundários, as cidades satélites e uma extensa 
periferia, que são os municípios vizinhos de Luziânia, Planaltina de Goiás, Padre Bernardo, Água Fria de Goiás, Valparaízo, Novo Gama, Cidade Ocidental, Águas Lindas e Santo Antônio do Descoberto. O aglomerado urbano recebe também o adjetivo de polinucleado devido a sua disposição sobre 0 espaço. A interdependência entre o núcleo e sua periferia é que faz de Brasília um aglomerado urbano.

O Distrito Federal é fruto da gestão do território e teve como principais agentes o Estado e os trabalhadores migrantes. O Estado agiu como projetista, promotor, construtor, financiador, e proprietário do solo. E os trabalhadores migrantes foram a grande massa de mão-de-obra que realizaram a construção de Brasília, e posteriormente seriam a maior parte dos moradores da nova capital.

No ano de inauguração de Brasília, já existiam além do Plano Piloto mais oito cidades satélites e o município de Luziânia, que está localizado fora dos limites do Distrito Federal, mas faz parte do aglomerado urbano. Duas das cidades satélites antecedem a criação de Brasília: Planaltina e Brazlândia. A Cidade Livre, Candangolândia, Taguatinga e Cruzeiro foram criadas por meio da mobilização dos trabalhadores. No mesmo ano da inauguração foram criadas por decisão do Estado, Gama e Sobradinho. Esse processo evidencia o inicio da criação de um aglomerado urbano.

O período de 1974 a 1987 foi marcado pela criação de planos de ordenamento do território do DF, em especial para a região do entorno. A preocupação do Estado com o ordenamento e consolidação de cidades já existentes no Entorno do DF reforçou o modelo de polinucleamento e consolidou a segregação no território. Não houve nesse período, políticas públicas de incentivos à instalação de indústrias no DF, predominando a atividade econômica terciária. 
O ano 1988 foi marcado pela consolidação do aglomerado urbano de Brasília. O governo local estendeu a oferta de lotes no DF, com o intuito de reverter o crescimento populacional para dentro dos limites do DF. Essa oferta gerou a criação de novas cidades satélites como Santa Maria, Riacho Fundo, Recanto das Emas e São Sebastião. Além dessas cidades surgiram no mesmo período inúmeros loteamentos clandestinos a partir do parcelamento privado da terra.

Brasília apresenta certas particularidades em seu processo de formação. A primeira delas é a sua concepção inicial de capital, cidade projetada, com meta de tamanho pré-definido, 500 mil habitantes no ano 2000. A segunda é a propriedade pública da terra. E a terceira é o território ser também um distrito, dando ao poder público autonomia pra gerir o uso e ocupação do solo a partir de instâncias decisórias confluentes.

Nenhuma dessas particularidades contribui de forma positiva para a consolidação de Brasília. O projeto desconsiderou a dinâmica da cidade. A propriedade da Terra funcionou como um elemento seletivo e não distributivo, e as instancias decisórias confluentes apareceram como uma limitação à autonomia política.

Outra particularidade do aglomerado bastante citada é o fato desse aglomerado ser bem jovem ainda. Contudo se observarmos o contexto histórico em que a capital se insere, chegaremos à conclusão que Brasília faz parte de uma história um tanto mais longa, que se inicia no século XVIII, nos denominados ciclos da mineração e da pecuária, evidenciado pela quantidade de fazendas a serem desapropriadas para a sua construção, tem continuidade na Missão Cruls no fim do século XIX e culmina com sua inauguração em 1960. 
Brasília foi concebida para solucionar os problemas brasileiros em termos de desenvolvimento regional e integração do território nacional e ao mesmo tempo para ser a capital da República, ou seja, centro de decisões políticas. Tinha ao mesmo tempo a função de irradiar desenvolvimento econômico para as demais regiões ultrapassando os limites do quadrilátero do Distrito Federal. E também deveria ter o território voltado para a função político-administrativa, preservando-se de qualquer outra atividade notável.

Dessa contradição em relação à função de Brasília emanaram novas contradições sobre o território. Brasília surgiu para ser sede político-administrativa do país e se projetou para abrigar apenas os servidores públicos que ali trabalhariam. Contudo, os responsáveis pela construção da cidade em tempo recorde, e que até então moravam em acampamentos também reivindicaram moradia na nova capital. E foi a partir de movimentos populares que surgiram as primeiras cidades satélites, antes mesmo que o Plano Piloto fosse ocupado. Iniciouse com a criação das cidades satélites, uma enorme segregação sócio-espacial, visto que as cidades recém criadas localizavam-se a certa distância do centro.

A detenção da posse da terra pelo Estado não foi suficiente para fazer de Brasília um território ordenado, diferente das demais regiões metropolitanas do país. Até a década de 70 praticamente não houve planejamento e o resultado disso é um aglomerado cuja periferia tem problemas piores ou iguais aos do restante do Brasil.

Dessa forma ficam evidentes os processos que ocorreram e ainda ocorrem no território do aglomerado. São eles: as fortes migrações, ausência de industrialização, função de capital federal, polarização das atividades terciárias no centro do aglomerado, monopólio estatal da terra urbana na implantação da cidade e valorização exagerada da terra urbana. 
A criação das cidades-satélites se dá nesse contexto e antes de ser uma solução para os problemas urbanos do aglomerado, aparece como uma continuidade da política habitacional segregacionista que se observa em Brasília desde sua criação. A retirada da população de baixa renda para a periferia ou a valorização exagerada da terra e conseqüente movimento da população do centro para as zonas periféricas são o retrato dessas políticas urbanas e habitacionais que geraram a segregação sócio-espacial das mais perversas.

As políticas urbanas e habitacionais as quais nos reportamos ignoram uma relação fundamental na criação de uma cidade, a relação entre moradia e trabalho. As cidades são constituídas para ser apenas dormitório dessa população, uma vez que a oferta de empregos fica toda concentrada no centro do aglomerado.

A necessidade de se ofertar moradia, antes de tudo, faz com que surjam inúmeras cidades-satélites, dentre elas Ceilândia cujo objetivo é transferir para a periferia os loteamentos do Plano Piloto. A criação da cidade-satélite de Ceilândia em 1971 com a remoção da Vila IAPI deslocou para a periferia mais de 80 mil habitantes. A remoção não se deu por acaso, uma cidade projetada e com uma meta de habitantes pré-definidos não poderia se permitir uma aglomeração e adensamento da malha urbana dessa proporção. Foi necessário, então, expulsar para a periferia a população que ali ousasse se instalar.

As famílias da Vila IAPI foram removidas contra sua vontade para um local sem infra-estrutura urbana ou comunitária, localizado a cerca de 30 quilômetros do Plano Piloto. A mudança das famílias representou uma grande perda social, pois causou uma significativa redução de sua renda devido à distância em relação ao centro de empregos. 
Além da redução da renda, a falta de equipamentos urbanos e comunitários reforçava a dependência em relação ao Plano Piloto e em relação ao Núcleo Bandeirante, mais dotado de serviços, comércios e atividades capazes de oferecer empregos.

Atualmente, Ceilândia ainda apresenta uma grande dependência em relação ao centro pela oferta de empregos e serviços. Entretanto já se observa um leve avanço, seja pela implementação de comércio local desde sua inauguração ou pela atração de novas atividades econômicas por meio da instalação de infraestrutura urbana e incentivos fiscais e econômicos como os do programa Pró-DF II.

\subsection{A Ocupação Irregular de Terras em Ceilândia}

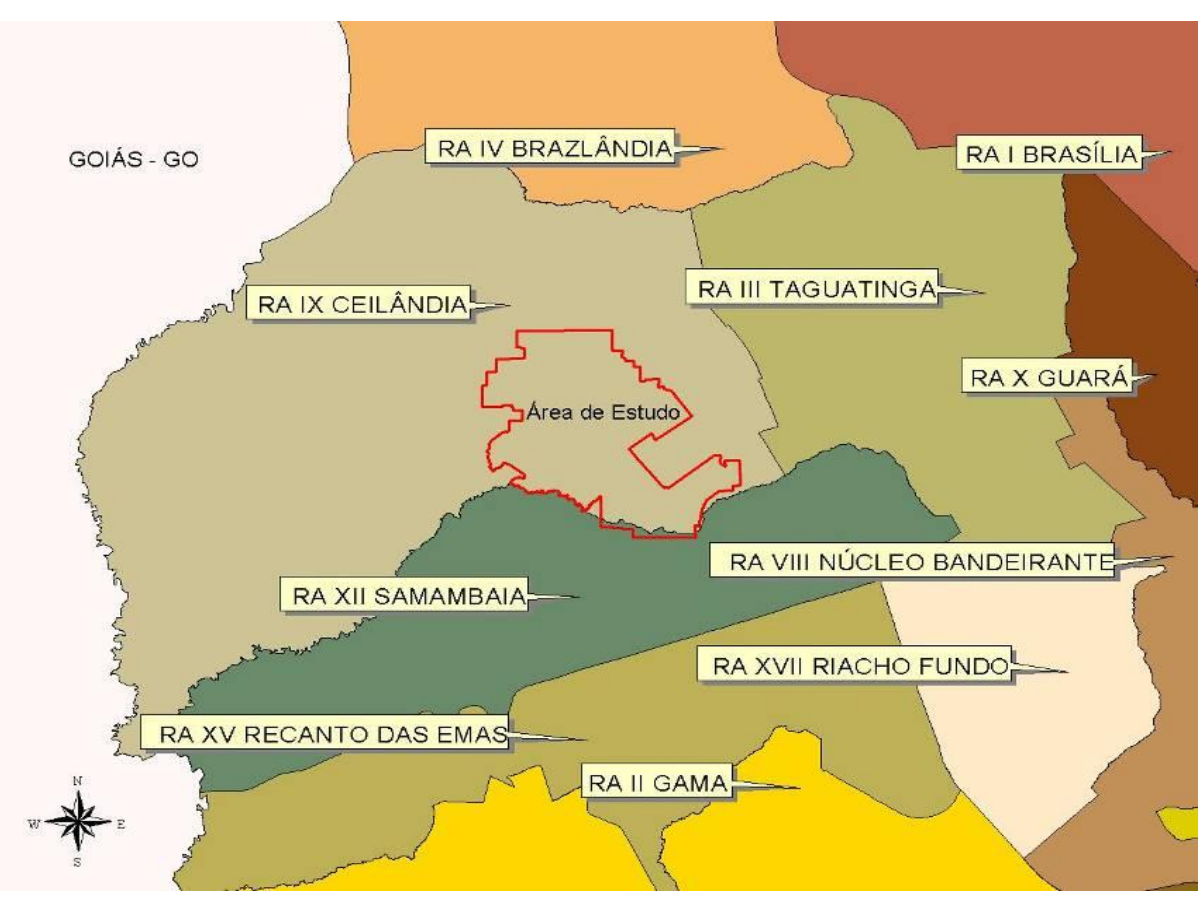

Ilustração 2: Mapa de localização das áreas de ocupação irregular de terras em Ceilândia Fonte: PROGEA - 2007, sem escala

No Distrito Federal o processo de ocupação irregular de terras se iniciou em 1975, no vale do Rio São Bartolomeu, com o condomínio Quintas da Alvorada. 
A tentativa de um planejamento de uso da terra pelo governo foi inútil, a área inclusive foi transformada em Área de Proteção Ambiental (APA). Mas já em 1984, surgiram lá os primeiros condomínios. De acordo com o Plano Diretor de Ordenamento Territorial (PDOT) de 1996, em 1989 já havia 174 loteamentos irregulares. A APA da Cafuringa foi criada em 1988, quando se iniciou o processo de ocupação no Colorado e adjacências. As áreas existentes até o momento de sua criação foram consideradas passiveis de regularização, ficando proibida a criação de novos condomínios até a aprovação no PDOT em 1992.

A criação de APAs ao mesmo tempo em que promoviam a proteção das áreas, promoviam também a valorização das terras já ocupadas e dos loteamentos que iam se formando, aumentando assim a especulação imobiliária presente em Brasília.

A cidade de Ceilândia é um exemplo claro de como se deu a formação espacial de Brasília. Como já mencionado, a cidade surgiu como uma forma de retirar do centro a população que lá se instalava. Em 1969, Brasília já tinha mais de 79 mil "favelados", ficando evidente a falta de êxito em se criar uma capital planejada para apenas 500 mil habitantes. Durante a administração do Governador Hélio Prates solicitou-se então a erradicação das favelas pela Secretária de Serviços Sociais, criando-se posteriormente a Comissão de Erradicação de Invasões.

Em 1971, foi lançada a pedra fundamental na cidade de Ceilândia e foram mandados para a região moradores da Vila IAPI, das Vilas Tenório, Esperança, Bernardo Sayão e Colombo, dos Morros do Querosene e do Urubu, e Curral das Éguas e Placa das Mercedes, invasões com mais de 15 mil barracos e mais de 80 mil moradores. 
Antes mesmo da consolidação de cidades como Ceilândia, Planaltina e Sobradinho, começaram a surgir novas invasões para abrigar a população que não foi atendida pela implantação das mesmas. Esse processo foi denominado por alguns de a periferia da periferia. Assim, invasões como Arapoanga, Mestre d'Armas e Vale do Amanhecer cresceram apoiadas em Planaltina e dela dependem. Do outro lado da cidade, Pôr do Sol e Sol Nascente são a extensão mais pobre de Ceilândia.

A periferia de Ceilândia (Ilustração I) surgiu há aproximadamente oito anos e já abriga 85 mil pessoas, cerca de um quarto da população da cidade. Devido à falta de infra-estrutura urbana, os moradores ainda dependem de Ceilândia para serviços como o de saúde e educação.

Os "condomínios" Sol Nascente e Pôr do Sol são um exemplo claro de Chácaras que foram parceladas, vendidas e ocupadas. Juntos o Sol Nascente e Pôr do Sol possuem uma população estimada de 74.100 habitantes, de baixa renda, com até cinco salários mínimos ocupando em torno de 16.983 lotes sem infraestrutura urbana e equipamentos públicos.

No ano de 2000, foi sancionada a Lei Complementar $n^{\circ} 330$ a qual foi alterada pela LC n 577/02, a lei previa a criação do Núcleo Habitacional Parque Sol Nascente. O objetivo era regularizar a invasão, ordenar a ocupação do solo, preservar a fauna e a flora, promover políticas sociais e econômicas, construir vias de acesso e instalar equipamentos públicos. Contudo ela foi julgada inconstitucional, e seus objetivos acabaram não sofrendo nenhuma regulamentação, propiciando que a área continuasse a ser invadida e sem nenhuma infra-estrutura.

Atualmente a área encontra-se em processo de regularização. Como se trata de assentamento de baixa renda, os estudos de impacto ambiental (EIA/RIMA) 
são realizados por empresa contratada pela administração pública. Tais estudos foram realizados pela empresa PROGEA. A empresa Saint-Germain Consultores Associados Ltda é a responsável pelo desenvolvimento social dos condomínios, no que diz respeito à instalação de infra-estrutura, equipamentos coletivos e projetos que visem à sustentabilidade ambiental e social na área.

As áreas citadas representam aproximadamente três mil hectares e desenvolvem-se entre os vales do rio Melchior e de seus afluentes e se formam a partir da área urbanizada da cidade de Ceilândia. Os loteamentos estão totalmente inseridos na Região Administrativa de Ceilândia - RA IX, parte em Zona Urbana de Dinamização - ZUD que corresponde ao "condomínio" Pôr do Sol e parte em Zona Rural de Uso Diversificado - ZRUD que corresponde ao "condomínio" Sol Nascente, incidindo sobre a Zona Rural, área Especial de Proteção Físico-ambiental denominadas bordas de Ceilândia.

Até a década de 90 a região era ocupada predominantemente por chácaras e pequenas fazendas com produção agropecuária. A partir de 1998 iniciouse o processo de invasão e fracionamento das unidades rurais dando início aos parcelamentos irregulares Sol Nascente e Pôr do Sol. Atualmente se observa a existência de loteamentos urbanos resultantes do fracionamento das chácaras em contraste com algumas chácaras que resistiram ao parcelamento em lotes habitacionais.

Trata-se de uma área que requer cuidados especiais visto que está inserida em uma área de conservação Ambiental. O PDOT de 1997 definiu os condomínios irregulares do Sol Nascente e Pôr do Sol como Área de Regularização de Interesse Social - ARIS e declarou também como Zona Especial de Interesse Social - ZEIS. 
O "Condomínio" Sol Nascente está situado nas Bordas de Ceilândia, ao sul. E confronta ao Norte com as quadras QNR, QNQ e QNP. A área em estudo está entre a zona urbanizada das citadas quadras de Ceilândia e o Rio Melchior. A área está entre as rodovias BR 070, DF 180 e DF 085 (EPTG), e ocupa os platôs formados pelos vales dos córregos afluentes do Rio Melchior.

O "condomínio" Pôr do Sol está situado nas Bordas Sul das quadras da QNP 34 e 35, e a Oeste da Área de Desenvolvimento Econômico (ADE) Centro Norte da Ceilândia no final da rodovia DF 085 (EPTG), encontra-se inserido na área Perimetral Sul. A sua Poligonal interfere com a Área de Relevante Interesse Ecológico do Parque JK.

Os condomínios irregulares possuem uma posição estratégica em relação à malha viária, visto que estão próximos às principais vias de acesso ao Plano Piloto, como VC-311, Via NM 3, DF-180, DF-085, BR-070, Avenida Hélio Prates, Avenida Elmo Serejo e Via de ligação Samambaia - Taguatinga. 


\section{O PROGRAMA DE APOIO AO DESENVOLVIMENTO PRODUTIVO - PRÓ - DF NA CEILÂNDIA: DIFERENÇAS ENTRE O MODELO IMPLANTADO E A IDÉIA DE POLOS DE CRESCIMENTTO DE FRANÇOIS PERROUX}

\subsection{A Idéia de Pólo de Crescimento de François Perroux}

François Perroux não foi o primeiro a elaborar um modelo de crescimento para a economia. Antes dele, G. Gassel e J. Schumpeter já haviam construído modelos que representavam a economia em crescimento. O primeiro apresentou um modelo de economia estacionária, na qual a população e a produção global crescem nas mesmas proporções, sem que haja aumento das taxas de lucro, mantendo-se ao longo do tempo o mesmo quadro econômico do período anterior. O segundo construiu um circuito ampliado em que população, produção e capital aumentam em igual proporção. Os fluxos aumentam sem modificar as estruturas e sem flutuações.

Tais modelos, no entanto não explicam o crescimento real da economia, visto que o crescimento econômico caracterizou-se, dentre outras coisas pelas flutuações, por progressos ou retrocessos e por mudanças estruturais.

As mudanças estruturais são caracterizadas pelo aparecimento ou desaparecimento de indústrias, pela participação de dadas indústrias num determinado período de tempo no produto industrial global e por taxas de crescimento diferentes para diferentes indústrias. Além da difusão de uma indústria ou grupo delas, seja pelo aparecimento ou crescimento, que gerem ao longo do tempo o surgimento de novas indústrias.

Segundo o economista François Perroux (1903-1987), o crescimento não ocorre simultaneamente por todo espaço de um país, ou cobrindo as diversas 
regiões de um lugar. Ao contrário, manifesta-se em pontos ou pólos de crescimento, com intensidades variáveis, expande-se por diversos canais e tem efeitos variáveis sobre toda a economia.

O crescimento econômico é próprio de áreas favorecidas por variadas circunstâncias, onde surge uma indústria motriz e, como conseqüência, como reflexo da ação desta indústria o crescimento se propaga, se expande, beneficiando as regiões que a cercam, que são para ela polarizadas. (ANDRADE, 1967, p. 58).

Esse modelo é explicado por meio da indústria motriz e o crescimento; pelo complexo de indústrias e o crescimento; e pela expansão dos pólos de crescimento e crescimento das economias nacionais.

A indústria motriz se desenvolve sob a forma de grande indústria moderna, e se caracteriza principalmente pela separação dos fatores de produção, concentração dos capitais sob um mesmo poder, decomposição técnica das tarefas e mecanização. Elas geralmente apresentam progresso técnico em fase inicial, com taxas de crescimento do produto mais elevadas que a média, até atingir um ponto ótimo, e sofrer declínio em seguida, em função da diminuição do progresso, da procura e da especulação.

A ação de uma indústria sobre outra se dá quando elas estão ligadas apenas pelo preço, ou seja, quando a maximização dos lucros depende apenas delas mesmas. Ou quando elas estão ligadas pela compra e venda de produtos no mercado de fatores, que dependem por sua vez de técnicas e de inovações. Sendo assim, os lucros de uma empresa podem ser formados ou induzidos pelas decisões de outras empresas.

Isso demonstra que o crescimento pode ocorrer em curto prazo, pela expansão de uma firma que investe em sua própria rentabilidade. E em longo prazo 
com crescimento de um conjunto de firmas por meio dos investimentos e em função dos lucros e vantagens induzidas.

O surgimento de uma nova indústria exerce uma ação sobre o produto global da economia porque o nascimento de uma nova indústria é fruto de uma expectativa, consubstanciando na medida em que seus realizadores assumem todos os riscos de sua realização e iniciam um processo de transformação na economia global pela utilização de fatores que provocam um deslocamento ou realocação dos fatores produtivos.

Quando a firma já está incorporada à economia ela contribui com sua própria participação e com a produção por ela induzida. Uma vez que, a inovação bem sucedida suscita a inovação por outros agentes e grupos. A inovação tem efeito desestabilizador pela introdução de variáveis diferentes ou suplementares no horizonte econômico e nos projetos dos grupos e agentes.

É necessário salientar que toda ação e inovação sobre a estrutura econômica também induz transformações nas estruturas sociais e nas características das instituições jurídicas e políticas. Tal análise, diferentemente da feita por J. Schumpeter, abrange as numerosas formas de concorrência monopolísticas e se abre ao conceito de complexo de indústria.

A análise de complexo de indústria passa pela compreensão de três elementos: a indústria-chave; o regime não concorrencial do complexo; e o fato da aglomeração territorial.

A indústria chave é a indústria motriz já mencionada. É aquela que age sobre uma movida gerando um aumento global nas vendas. A indústria chave representa um ponto privilegiado de aplicação das forças ou dinamismos de crescimento, que provocam também o crescimento e expansão do conjunto. 
Mesmo tratando-se de oligopólios, o regime do complexo industrial não é estável, pois outros fatores agem desestabilizando-o, como, por exemplo, os fatores de subordinação e a instabilidade de preços e de quantidades.

A aglomeração territorial por sua vez intensifica as atividades econômicas, devido à proximidade e aos contatos humanos. E adiciona conseqüências especificas a formação de indústrias-chave e ao regime não concorrencial. A aglomeração industrial-urbana suscita padrões de consumo diversos e em progressão, além de incitarem necessidades como habitação, transporte e serviços públicos, que exercem grande participação no desenvolvimento econômico. As mudanças podem ocorrer localmente e podem ter efeito a nível nacional, em intensidade variável, e podendo formar outros centros de acumulação e aglomeração urbanos.

A economia nacional não se apresenta mais como um território politicamente organizado, mas como uma combinação de um conjunto de ativos (indústrias motrizes, pólos de indústrias e de atividades geograficamente aglomerados) e um conjunto de passivos relativamente (indústrias movidas, regiões dependentes dos pólos geograficamente aglomerados). Sendo que os primeiros transmitem aos últimos o fenômeno do desenvolvimento.

O que se observa atualmente, não é mais o dualismo entre Estado e instituições financeiras, mas sim grandes unidades econômicas servindo de instrumentos da prosperidade e como arma para o poderio do Estado Nacional, sendo cada vez mais comum a combinação de capital púbico e privado. Contudo, não deixa de existir a dialética entre os espaços de crescimento, gerados pelos pólos de crescimento e espaços territoriais politicamente organizados. Ainda que tais 
conflitos não se apresentem como violentos, apresentam-se como entraves ao crescimento econômico.

\subsection{Programa de Apoio ao Desenvolvimento Produtivo - Pró-DF}

De acordo com Relatório Urbanístico ${ }^{1}$ realizado pela Secretária de Estado de Planejamento e Gestão e pela Secretária de Desenvolvimento Econômico e Turismo a fim de identificar e avaliar os aspectos relacionados com a inserção das Áreas de Desenvolvimento Econômico - ADEs no contexto de ordenamento territorial do Distrito Federal e do Entorno, o programa ADE PRÓ-CIDADES busca o desenvolvimento e a consolidação das Áreas de Desenvolvimento Econômico do DF por meio do desenvolvimento prioritário de infra-estrutura urbana.

As ADEs foram pensadas para estimular o desenvolvimento sustentável dos núcleos urbanos nos quais estão inseridas. Pode ser considerada como a principal estratégia do Governo do DF para reverter o quadro de elevado desemprego na Região e introduzir um elemento de dinamismo na economia local, também representa uma tentativa de descentralização das atividades econômicas do Plano Piloto, que resultaria na diminuição do fluxo de pessoas para o centro além de dar certa autonomia às cidades nas quais as ADEs estão instaladas.

O foco dessa estratégia é o programa denominado de Pró-DF, criado em 1996. Basicamente, este consiste em um amplo leque de incentivos capaz de tornar

\footnotetext{
${ }^{1}$ Trata-se de uma versão preliminar do Relatório Urbanístico realizado pela Prisma Consultoria em dezembro de 2008.
} 
Brasília um pólo de atração de investimentos e, dessa forma, atingir os objetivos como elevar a oferta de novos empregos e dinamizar a economia regional.

O Programa de Desenvolvimento Econômico Integrado e Sustentável do Distrito Federal, o Pró-DF criado pela Lei 2.427 de 14 de julho de 1999, tinha o intuito de implantar as ADEs e dinamizar a economia do DF como um todo. A primeira fase do Programa foi até 2003, e tinha como objetivo apoiar a iniciativa de negócios que produzissem bens e serviços, gerassem emprego e renda, e elevassem a contribuição tributária para o DF.

A partir de 2004, está sendo aplicado no Distrito Federal o Programa de Apoio ao Desenvolvimento Produtivo (Pró-DF II), definido na Lei 3.196-DF, de 29 de setembro de 2003, que concede incentivos fiscais e econômicos a empresas que se instalarem em Brasília e nas suas cidades-satélites.

Um dos principais incentivos ao Pró-DF que se manteve, é o incentivo creditício que financia até $70 \%$ do valor do Imposto sobre Circulação de Mercadorias e Serviços (ICMS) devidos, os juros são reduzidos e há 15 anos de carência. O beneficio foi estendido para o Imposto sobre Serviço de Qualquer Natureza (ISSQN), favorecendo também os prestadores de serviços no Pró-DF II.

Benefícios fiscais como a isenção do Imposto sobre Transmissão de Bens Imóveis (ITBI) e o Imposto Predial e Territorial Urbano (IPTU) se mantiveram. E novos incentivos foram introduzidos como a redução do Imposto sobre Propriedade de Veículos Automotores (IPVA) para veículos de transporte, por dois anos, e da Taxa de Limpeza Pública (TLP), por cinco anos.

O Pró-DF II manteve também a possibilidade de concessão de terrenos para instalação de empreendimentos, estabelecendo exigências relativas a prazos de pagamento e carência, com descontos que podem chegar a 95\% nos preços dos 
lotes ofertados pela Companhia Imobiliária de Brasília (Terracap). O Banco de Brasília (BRB) é o principal agente financeiro do projeto, sendo o principal encarregado de oferecer linha de crédito para as micros e pequenas empresas, com juros abaixo dos praticados pelo mercado, mobilizando para isso recursos do Fundo de Desenvolvimento do Distrito Federal (Fundefe).

Apesar dos incentivos fiscais e creditícios o programa ainda não conseguiu atingir suas propostas. Segundo o Governo do Distrito Federal o principal entrave está na falta de infra-estrutura e saneamento básico, que dificultam a atração de clientes e o escoamento da produção, visto que boa parte das ADEs não é dotada de pavimentação, iluminação pública, esgotamento sanitário, mobiliário urbano, abastecimento urbano, entre outras coisas. A principal estratégia do atual governo é, portanto o investimento em infra-estrutura e saneamento básico.

Outros fatores também podem ser enumerados como adversos ao desenvolvimento das atividades nas ADEs, são eles: a falta de investimentos pelos proprietários em seus estabelecimentos, a falta de segurança, a falta de capacitação gerencial dos empreendedores, a falta de qualificação da mão-de-obra local e conseqüente baixo nível de renda, além da falta de informação sobre as atividades instaladas, que prejudicam a formulação de uma política adequada para cada localidade. 


\subsubsection{ADE's em Ceilândia}

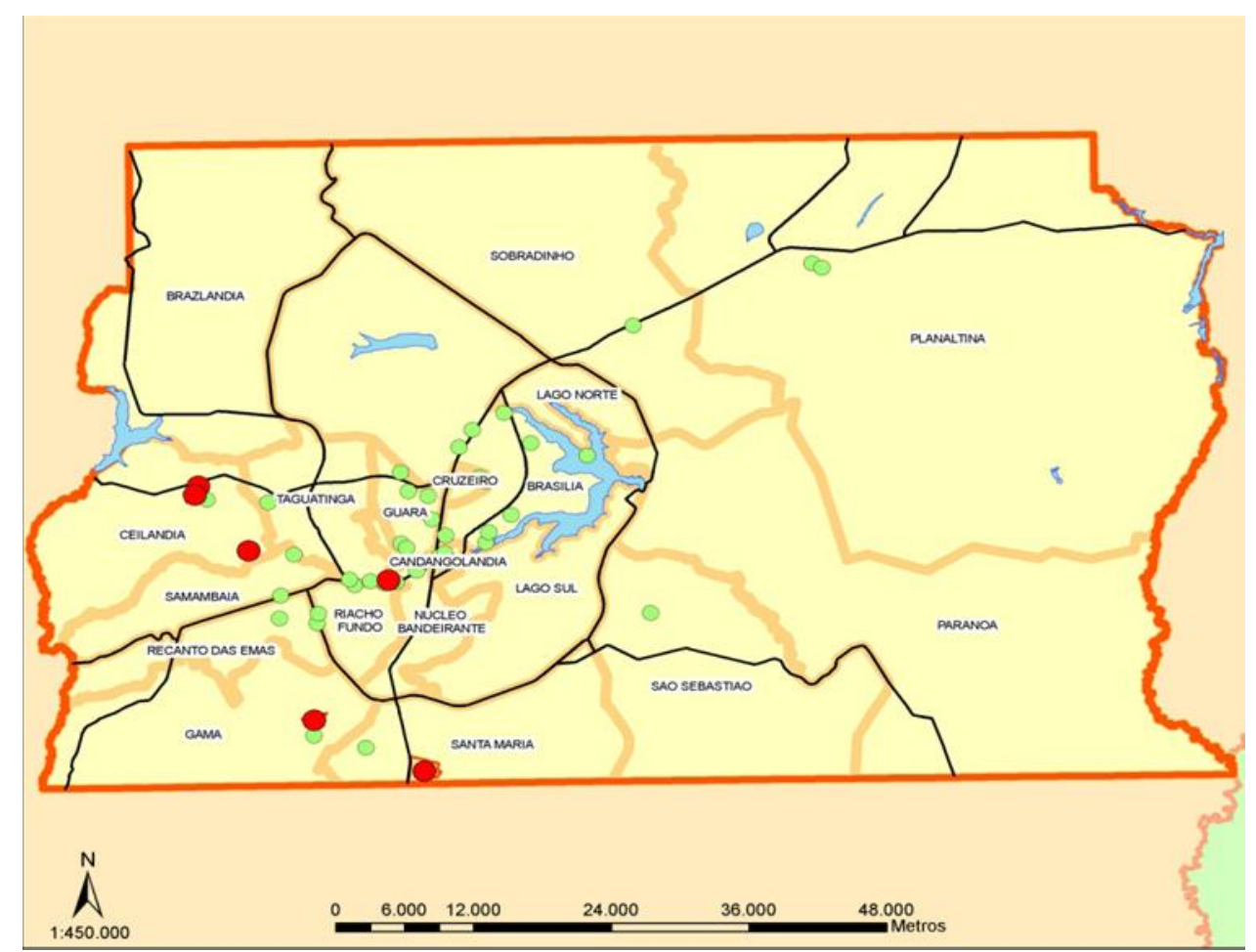

Ilustração 3: mapa de localização das ADE Fonte: SEDUH

Ceilândia possui três áreas de desenvolvimento econômico conforme demonstrado na ilustração 3, classificadas na categoria de uso como não consolidadas e fazem parte de projeto de dinamização e revitalização de áreas degradadas conforme previsto no Plano Direto de Ordenamento Territorial (PDOT) de 2007. As ADEs são divididas ainda em relação à ocupação. A categoria 1 corresponde a área não ocupada, a categoria 2 corresponde à ADE onde não há ocupação de uso misto como a ADE Setor Material de Construção e Setor de Indústria de Ceilândia, e a categoria 3 é uma área com baixa e média ocupação de uso misto e com tendência à alta ocupação, como a ADE Centro Norte.

Em termos de oferta de emprego, as ADE's de Ceilândia ainda não representam uma solução. O surgimento das novas empresas representa um crescimento pequeno no número total de estabelecimentos na RA de Ceilândia. $\mathrm{A}$ 
oferta de postos de trabalho continua concentrada no Plano Piloto e não há perspectiva de que ele seja redirecionado para as cidades satélites, embora a Ceilândia tenha apresentado um crescimento em termos de comércio local e atraia para si um mercado consumidor representativo.

Em censo realizado nas ADE por empresa contratada da Secretária de Estado de Desenvolvimento e Turismo verificamos que a ADE Centro-Norte oferece um total de 1.167 postos de trabalho. Desses 637 são ofertados pelo ramo de comércio e reparação de veículos automotores e motocicletas e 302 pela indústria de transformação. A ADE Setor de Indústria promove o emprego de 1.039 pessoas, sendo 605 na indústria de transformação e 323 no comércio e reparação de veículos automotores e motocicletas. A ADE Setor de Materiais de Construção oferece 561 empregos, desses 237 são na indústria de transformação, 233 no comércio e reparação de veículos automotores e motocicletas e 81 no transporte, armazenagem e correio.

\subsubsection{ADE Centro-Norte em Ceilândia}

A ADE Centro-Norte de Ceilândia está localizada no limite sul da área urbanizada da Região Administrativa de Ceilândia, na lateral da Estrada Parque Centro-Norte - EPCN (rodovia DF 085), ao lado do condomínio Pôr do Sol e próximo ao Setor Residencial QNP da Ceilândia. A ADE encontra-se na faixa de transição entre a área urbanizada e a borda de chapadas que corresponde ao limite físicoambiental da expansão urbana nas direções oeste e sul da cidade. A ARIE (Área de 
Relevante Interesse Ecológico) JK foi criada com o objetivo de conservação dessa área e fica ao sul da ADE, contudo os parcelamentos irregulares de chácaras como o Pôr do Sol continuam a avançar. A ADE Centro-Norte terá ao norte o corredor de atividades que está em construção. Tal corredor de atividades está previsto no PDL de Ceilândia de 2000 e faz parte do projeto de criação de um novo centro regional, uma área de dinamização urbana que se dá a partir da conurbação das cidades de Ceilândia, Taguatinga e Samambaia.

Essa ADE possui uma área de $549.000 \mathrm{~m}^{2}$, distribuídas em quatro quadras, parceladas em 625 lotes destinados para uso comercial, e de bens e serviços. Da área total, 35,37\% estão destinadas às unidades imobiliárias, 29,47\% ao sistema de circulação e 35,16\% aos espaços livres, de uso público (áreas verdes e parques). As principais atividades desenvolvidas são de micro-empresas como oficinas mecânicas, serralherias e oficinas gráficas. A princípio o objetivo da ADE era regularizar os empreendimentos de pequeno porte como os já citados, por isso a maioria dos lotes chega somente a $500 \mathrm{~m}^{2}$. Esse fato, entre outros, facilita o uso misto nessa ADE, embora isso não seja permitido por lei.

A ADE Centro-Norte possui boa acessibilidade e suporta por isso as mais diversas atividades. A ADE já foi dotada de infra-estrutura básica e inaugurada. Entretanto os quatro equipamentos públicos previstos como o equipamento público de porte regional, equipamento de segurança pública, clube ou associação recreativa e o lote destinado à Secretaria de Meio ambiente e tecnologia SEMATEC ainda não foram implantados.

Observando-se a ocupação da ADE Centro-Norte na ilustração 4 já é possível deduzir que o programa Pró-DF não atingiu plenamente seus objetivos. Apesar de 472 lotes possuírem algum tipo de ocupação, apenas 275 desempenham 
o papel para o qual foram criados, ou seja, em dez anos de existência a ADE Centro-Norte só conseguiu ocupar $40 \%$ da área prevista. Além de 152 lotes ainda estarem vazios, existem ainda 28 construções abandonadas, 29 ainda estão sendo construídas, 121 estão acabadas, mas não tem qualquer tipo de ocupação, 7 lotes foram invadidos e 10 tem ocupação residencial.

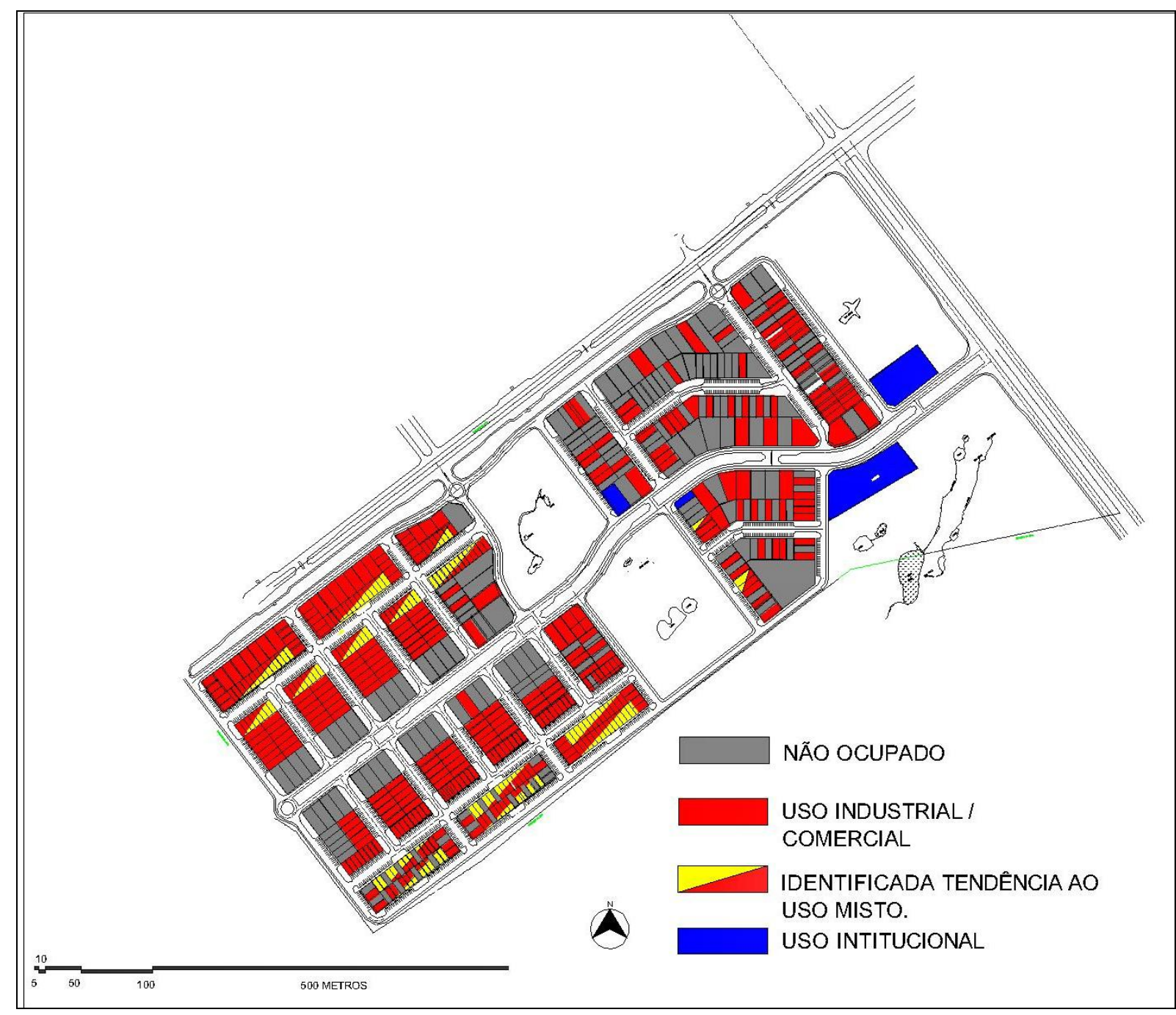

llustração 4: Uso e ocupação da ADE Centro-Norte

Fonte: Sete Serviços Técnicos Especializados Ltda, s.d 


\subsubsection{ADE Setor de Indústria de Ceilândia}

O Setor de Indústrias de Ceilândia foi criado na década de 80 , sendo composto por lotes destinados a uso comercial de bens e serviços, e de uso coletivo com objetivo de incrementar a economia local. O Setor possui 1.739 lotes divididos em 20 quadras

O Setor de Indústrias de Ceilândia está localizado na lateral da rodovia BR070. Limita-se ao leste o setor residencial QNO, ao sul com a QNQ e QNR, ao oeste com parcelamentos irregulares recentes e ao norte com a ADE Setor de Depósito de Materiais de Construção.

A rodovia BR- 070 é um eixo viário de grande importância urbana e regional, visto que além de fazer a ligação de Ceilândia com o Plano Piloto, também liga o DF com a porção oeste de Goiás, passando pela cidade de Águas Lindas, que é a maior cidade dormitório do entorno do DF. Isso faz com que a ADE se posicione de forma estratégica em relação ao acesso norte do Distrito Federal, pela via estrutural.

A ADE foi concebida como uma forma de controlar o uso do solo na Ceilândia, já que há uma tendência à expansão da cidade nas bordas da chapada. Contudo o que se verifica é a criação de loteamentos irregulares próximos à ADE. Isso coloca a ADE Setor de Indústria e a ADE Setor de Materiais de Construção em uma situação similar, duas glebas praticamente vazias entre a zona de ocupação irregular e a cidade de Ceilândia. 
O setor de indústria de Ceilândia (SIC) ainda não foi consolidado e existem 987 lotes que ainda estão vazios. Apenas 357 lotes estão de fato ocupados, ou seja, 20,50\%. Existem no setor 48 construções abandonadas, 58 em andamento, 219 construções terminadas, mas sem nenhuma ocupação, 22 construções acabadas com ocupação, 18 lotes invadidos, 80 lotes ocupados pelo Governo do Distrito Federal e 40 lotes com ocupação residencial.

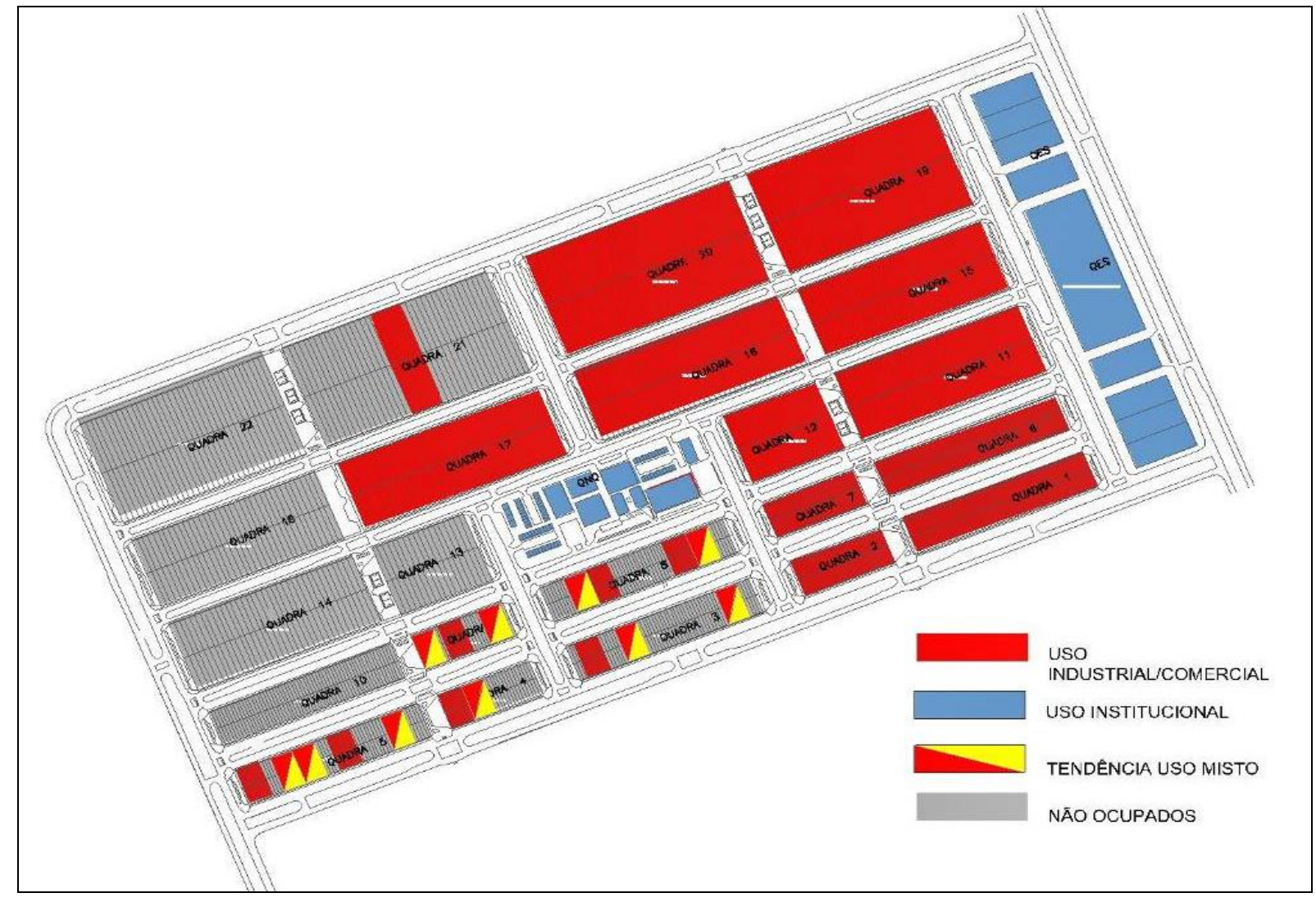

llustração 5: Uso e ocupação da ADE Setor de Indústria

Fonte: Sete Serviços Técnicos Especializados Ltda, s.d. 


\subsubsection{ADE Setor de Materiais de construção de Ceilândia}

O Setor de Materiais de Construção limita-se ao norte com rodovia BR-070, a leste com o setor residencial da Expansão do Setor $O$, ao sul com as quadras residenciais QNQ, QNR e Setor de Indústrias de Ceilândia e a oeste com loteamentos irregulares recentes. O acesso viário ao local pela BR-070 faz dessa ADE um local estratégico na implantação de investimentos econômicos e de infraestrutura. A ADE de Materiais de Construção assim como o Setor de Indústria também funciona como uma faixa de contenção para novos loteamentos.

A ADE possui uma área de $415.000 \mathrm{~m}^{2}$, distribuídas em nove quadras, com um total de 430 lotes entre 900 e $1050 \mathrm{~m}^{2}$, o que propicia a instalação de indústrias de grande porte. Além do comércio de bens e serviços e armazenagem, existe no local também a oferta de comércio de consumo pessoal e saúde, consumo eventual, e comércio de prestação de serviços, tais como bares, restaurantes, serviços pessoais, e de restauração e reparação. Atualmente estão em funcionamento 92 empresas que geram um total de 561 empregos.

A implantação do Setor ocorreu na década de 90 , mas devido à falta de investimentos o Setor possui menos de $30 \%$ da sua capacidade utilizada. O projeto inicial prevê a criação de praças e instalação de equipamentos comunitários, entretanto, duas décadas depois, o projeto não foi executado e contribui para a sensação de abandono no local.

O Setor de Materiais de Construção possui 303 lotes com algum tipo de ocupação. Contudo, nem todos os lotes tem sua ocupação destinada ao fim para 
que foram planejados. Além de 125 lotes ainda estarem vazios, existem ainda 17 construções abandonadas, 21 ainda estão sendo construídas, 113 estão acabadas, mas não tem qualquer tipo de ocupação, 8 lotes foram invadidos e 2 tem ocupação residencial.

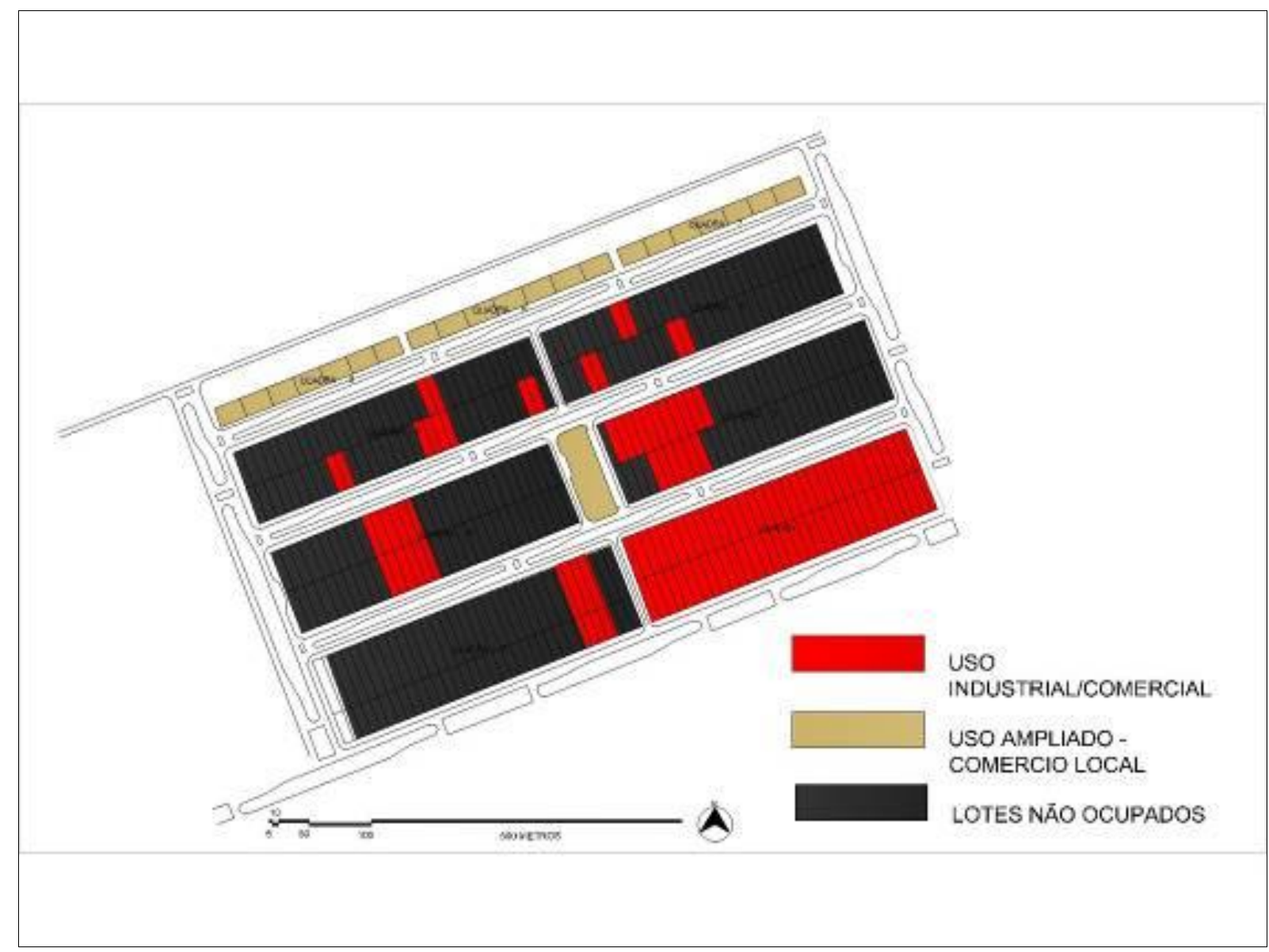

Ilustração 6: Uso e Ocupação da ADE Setor Material de Construção

Fonte: Sete Serviços Técnicos Especializados Ltda, s.d 


\subsection{ATÉ QUE PONTO AS ÁREAS DE DESENVOVIMENTO ECONÔMICO EM CEILÂNDIA FUNCIONAM COMO IMPULSIONADORAS DA GERAÇÃO DO DESENVOVIMENTO PARA A REGIÃO}

Segundo o modelo de desenvolvimento proposto por François Perroux, o desenvolvimento sobre determinado espaço geográfico se dá mediante o surgimento de uma nova indústria. Ele considera a inserção de um elemento de inovação como fundamental para a criação de um ambiente propício ao crescimento econômico de dada região.

A nova indústria, denominada indústria motriz, deve ser capaz de gerar mudanças ligadas aos produtos tanto para trás quanto para frente, gerando um aumento das taxas de crescimento do complexo como um todo. Além de considerar os elementos como indústria motriz, complexo de indústria e o crescimento da economia nacional, já mencionados anteriormente, a análise dos pólos de crescimento supõe uma inter-relação entre as indústrias principais e o complexo industrial e uma inter-relação entre o crescimento dos grupos industriais e 0 crescimento da nação.

No Brasil, desde a década de 70, adotou-se uma estratégia no sentido de fortalecer e criar pólos de desenvolvimento. Essas estratégias tiveram sua base numa economia exportadora, com a melhoria da infra-estrutura e promoção da interligação regional e nacional, através do sistema de telecomunicações. O objetivo dessas políticas era a descentralização do desenvolvimento, uma tentativa de diminuir as desigualdades econômicas e sociais pelo território brasileiro, que foram frutos de sua formação espacial. 
As iniciativas do Governo Federal de promover o desenvolvimento de forma mais uniforme tem como fundamento a transformação na estrutura econômica e social, a partir da capacitação em termos sociais e produtivos e promover e distribuir a renda em padrões compatíveis com aqueles observados nas regiões mais desenvolvidas do país. Alguns programas elaborados pelo Governo Federal nesse sentido são o Programa de Integração Nacional (PIN), o Programa de Desenvolvimento de Áreas Integradas do Nordeste (POLONORDESTE), o Programa de Apoio ao Desenvolvimento da Região semi-árida do Nordeste (Projeto Sertanejo), o Programa de Pólos Agropecuários e Agrominerais da Amazônia (POLOMAZÔNIA), o Programa de Desenvolvimento dos Cerrados (POLOCENTRO), entre tantos outros que tiveram resultados diferenciados em cada região e por vezes geraram problemas ambientais nas regiões onde foram implementados, fazendo surgir a partir da década de 80 a noção zoneamento ecológico-econômico, impondo-se limites nas relações de produção e estabelecendo-se diretrizes para a conservação e recuperação ambiental e econômica.

A partir da década de 90, outro conceito assume um papel de destaque no planejamento urbano, é o de eixo de desenvolvimento. Iniciam-se um processo de valorização das estruturas de transportes com vistas a desenvolver as fronteiras econômicas, atender o escoamento da produção e abastecer de insumos e matérias-primas todas as regiões.

As políticas em âmbito nacional devem ser adotadas em complementaridade com as políticas locais e nesse sentido devem-se observar os seguintes elementos: aumento da autonomia regional para a tomada de decisões, crescimento da capacidade para reter e reinvestir o excedente econômico gerado 
pelo processo de desenvolvimento, crescente processo de indução social e um processo permanente de conservação e preservação do ecossistema regional.

Observados esses elementos, a introdução de uma indústria pode desencadear desenvolvimento em uma dada região. Contudo, os efeitos podem ser distintos em termos de oferta de emprego, de geração de renda, de produtividade e de arrecadação fiscal. Podemos verificar tanto efeitos de dispersão, quanto encadeamentos pra trás ou para frente, gerando o aumento da produção de insumos e matérias-primas ou induzindo a demanda de bens de consumo e de capital pelo aumento do lucro.

Brasília apresenta certas particularidades no contexto nacional. O fato de Brasília ser essencialmente urbana e ter uma taxa de crescimento de 2,8\% ao ano não foram suficientes para a cidade desenvolver nenhuma atividade econômica de grande peso. Pois o Distrito Federal acumula o papel de centro administrativo nacional, o que faz com que haja uma relativa estabilidade em sua economia com forte base no setor terciário, sendo que a administração pública corresponde à 40,49\% das atividades econômicas.

De certa forma Brasília apresenta certa vantagem na atração de investimentos em relação às demais regiões metropolitanas do mesmo porte visto que a ausência de uma atividade econômica especifica abre espaço para o desenvolvimento de qualquer atividade a partir das potencialidades ainda não exploradas.

O Plano Piloto concentra a oferta de empregos e oportunidades de trabalho. De acordo com dados da RAIS (Relação Anual de Informações Sociais) de dezembro de 2002, a região central do aglomerado concentrava $39,70 \%$ dos 
estabelecimentos de todos os setores econômicos do DF, seguido por Taguatinga com 17,73\% e Guará com 10,35\%. A concentração das atividades econômicas no Plano Piloto evidencia as políticas públicas que privilegiaram a fixação da população na periferia da cidade, mas não estimularam a criação de postos de trabalhos nas cidades-satélites.

Numa tentativa de reverter esse quadro foram criadas as ADEs. Assim como o Pólo de Crescimento, as ADE's têm por objetivo desencadear desenvolvimento não só para área onde está inserida, mas também para a região que a cerca. As ADE's são uma tentativa do governo local de promover nas cidadessatélites a criação de um pólo de atração de investimento, descentralizando as atividades econômicas e dinamizando a economia das regiões onde foram instaladas e promovendo conseqüentemente o aumento da oferta de empregos e arrecadação tributária.

Contudo as ADE's ainda não conseguiram atingir as metas para elas estabelecidas. De acordo com dados do Ministério do Trabalho entre os anos de 2002 e 2006 não houve um aumento significativo no numero de estabelecimentos econômicos na Ceilândia, que se situam em torno de 2.500 estabelecimentos, perpetuando-se o modelo anterior de concentração no centro do aglomerado. Esses dados nos permitem inferir que a simples criação de setores para o desenvolvimento de dada atividade não são suficientes para reverter um quadro de polarização de atividades econômicas.

Alguns fatores como a concentração humana, a malha viária disponível e a concentração das atividades sobre o espaço deveriam contribuir para a aceleração do desenvolvimento na região. Entretanto, a falta de investimentos em infra-estrutura 
acaba por afastar a possibilidade de consolidação dos setores com a ocupação de todos os lotes.

Diante disso as áreas de desenvolvimento não conseguem se estabelecer como indutoras do crescimento e nem tão pouco representar no futuro a solução dos problemas de desemprego do aglomerado urbano. São nítidas as diferenças entre as Áreas de desenvolvimento econômico instituídas na Ceilândia e o modelo de pólo de crescimento proposto por Perroux.

Uma das diferenças entre o modelo de Perroux e as ADE's é a ausência na ADE de um elemento fundamental para existência de um pólo de crescimento. Ainda que a criação das ADE's represente um elemento novo na economia como um todo, as empresas não podem ser consideradas verdadeiramente como indústrias motrizes, já que boa parte das indústrias preexiste à criação das ADE's e tem a partir delas a possibilidade de se formalizarem. E ainda as que foram criadas posteriormente não foram capazes de gerar a criação de outras, já que passados mais ou menos dez anos da criação de quase todas as ADE's não se conseguiu a consolidação dos setores, pelo menos os localizados na Ceilândia, com ocupação total dos lotes lá ofertados.

As empresas instaladas, de forma geral, não apresentam um nível de interrelação como prega o modelo de Perroux. São empresas de pequeno porte, com pouca capacidade de inovação tecnológica e de processos produtivos mais eficientes, que poderiam gerar uma rede de relações produtivas sobre o território. No caso de Ceilândia a simples concentração de empresas, de um mercado consumidor e de um mercado de mão-de-obra não é suficiente para gerar uma rede de relações em torno do território. 
A criação centro regional autônomo como previsto no PDOT ainda está longe de ser materializado. A criação de setores voltados para atividade econômica e a abertura de vias de acesso para escoamento de produção e para facilidade de acesso tanto do mercado consumidor a quanto de empresas em busca de insumos são primordiais para o crescimento das cidades. Contudo, esses fatores devem vir seguidos de melhorias sociais, como oferta de moradias, saúde, segurança, qualificação de mão-de-obra, preservação ambiental, além de coesão política. Uma vez que o crescimento não pode se dar de forma estanque, os políticos tem que assumi-lo como um processo continuo e não como um projeto que se inicia a cada mandato. 


\section{CONSIDERAÇÕES FINAIS}

O presente trabalho teve como finalidade retratar a ocupação irregular de terras e a criação de centros de desenvolvimento econômico em Ceilândia a partir das informações e análises apresentadas nos itens anteriores. Apesar da falta de dados para uma análise da contribuição da aglomeração urbana para o desenvolvimento das atividades econômicas, nota-se que a ocupação irregular de terras nas bordas da Ceilândia não funciona como elemento de indução das atividades nas ADEs. $O$ fato da criação das ADEs e o início do parcelamento ocorrer de forma paralela, não estabelecem um vinculo de dependência entre os dois.

Ceilândia possui a maior população dentre as RA s do Distrito Federal. Esse fato deveria por si só representar um atrativo na instalação de empresas na cidade, uma vez que representa o maior mercado consumidor. Entretanto ainda é pequeno o número de estabelecimentos na RA em comparação ao centro do aglomerado. Com exceção do comércio capaz de atrair um grande número de consumidores, outras atividades econômicas têm pouca representatividade.

Juntas, as ADEs da Ceilândia ofertam apenas 1167 empregos, um número quase insignificante perto da população economicamente ativa de 160 mil habitantes. A população da cidade ainda busca no Plano Piloto ou em outras cidades satélites empregos, que devido ao baixo nível de escolaridade se concentra no comércio e serviços gerais.

O que se observa é que as ADEs em Ceilândia foram criadas para de certa forma conter o avanço dos parcelamentos irregulares nas bordas da cidade. Apesar de a cidade oferecer um contingente de mão-de-obra e certa confluência de 
fatores propícios ao desenvolvimento, os problemas sociais restringem esse desenvolvimento.

Conclui-se, então, que a criação de áreas polarizadas nas cidadessatélites capazes de reverter o desenvolvimento econômico e a oferta de empregos para a periferia do aglomerado depende de uma mudança na estrutura social da cidade, que privilegiem a capacitação profissional de seus moradores, uma política habitacional que dispense a necessidade de invadir e ocupar áreas públicas ou de fins rurais, e ainda que privilegiem a saúde, segurança e educação dentro de cada cidade-satélite. 


\section{REFERÊNCIAS BIBLIOGRÁFICAS}

ANDRADE, Manuel Correia de. Espaço, Polarização e Desenvolvimento: Uma Introdução à Economia Regional. São Paulo: Editora Atlas, 5ํedição, 1987.

BECKER, Bertha K. e EGLER, Claúdio A.G..Capítulo 5: O legado da modernização conservadora e a reestruturação do território. In Brasil: uma nova potência

HILLHORST, J.G.M. Planejamento Regional - Enfoque Sobre Sistemas. Rio de Janeiro, Zahar:1975.

GREGORY, Derek; MARTIN, Ron \& SMITH (orgs). Geografia Humana: Zahar. Rio de Janeiro. 1994.

MEIRELLES, Hely Lopes. Direito Municipal Brasileiro. 6aㅗ edição. São Paulo: Malheiros, 1993.

SANTOS, Milton. Metamorfoses do Espaço Habitado - Fundamentos teóricos e metodológicos da geografia. São Paulo: Hucitec, 1997. Rio de Janeiro: Bertrand Brasil, 1993. p. 169-213.

SPERIDIÃO, Faisol. Urbanização e regionalização, relações com o desenvolvimento econômico. Rio de Janeiro: IBGE, 1975.

PAVIANI, Aldo (Org.). A Conquista da Cidade: Movimentos Populares em Brasília. Brasília, Editora Universidade de Brasília, 1991.

PAVIANI, Aldo (Org.). Brasília: Moradia e Exclusão. Brasília: Editora Universidade de Brasília, 1996.

PAVIANI, Aldo (Org.). Brasília - gestão urbana: conflitos e cidadania. Brasília: Editora Universidade de Brasília, 1999.

PERROUX, François. O Conceito de Pólo de Desenvolvimento. In Schwartzman, J. (org.) Economia Regional: textos escolhidos. Belo Horizonte: CEDEPLAR, 1977. (Primeira edição: Note sur la notion de póle de croissance, 1955). 
RODRIGUES, Arlete Moysés. Direito à cidade e o Estatuto da cidade. Revista Cidades. Volume 2, Número 3. GEU: Presidente Prudente, São Paulo: 2005.

RELATÓRIO de urbanização, saneamento e desenvolvimento econômico. ADEs da Ceilândia: Centro-norte, Materiais de construção e Setor de indústria - projeto-piloto. Governo do Distrito Federal Secretaria de Estado de Planejamento e Gestão Secretaria de Estado de Desenvolvimento Econômico e Turismo

Sites:

www.seduma.df.gov.br

www.comparques.df.gov.br

www.seduh.df.gov.br

www.ceilandia.df.gov.br

www.cidades.gov.br/secretarias-nacionais/programas-urbanos 